\title{
PRIVACY IN TORT LAW- WERE WARREN AND BRANDEIS WRONG?
}

\author{
Harry KaLven, JR**
}

"... no other tort has received such an outpouring of comment in advocacy of its existence."

Prosser, Torts ro5r (Ist ed. r94r).

Privacy is one of the truly profound values for a civilized society, and it is heartening to find it today the subject of active interest and concern on many fronts. Several popular books have sounded alarm about the threats of surveillance that modern technology may carry, ${ }^{1}$ and an impressive committee of the Association of the Bar of the City of New York has for some years now been at work exploring the matter ${ }^{2}$ At the constitutional level, there have been the new emphases of some of the opinions in the birth control cases, finding in privacy a touchstone for constitutional policy, a sort of culminating right derived from the specific provisions of the Bill of Rights read together. ${ }^{3}$ In jurisprudence, there has been the sustained debate between Lord Devlin and Professor H. L. A. Hart on the limits of legal enforcement of morality, a debate which can well be said to turn on the protection to be afforded consensual adult. conduct when private. ${ }^{4}$ The psychologist tells us the importance to the child of a room of his own, and the sociologist describes for us the terrible attrition of places of privacy in modern life. And, if necessary, our still vivid experiences with totalitarianism remind us that a major tactic for the dictator is to subjugate by eliminating privacy. $^{5}$ I start, therefore, from the premise that privacy is surely deeply linked to individual dignity and the needs of human existence.

- A.B. 1935, J.D. 1938, University of Chicago. Professor of Law, University of Chicago. Author, The Negro and the First Amendment (1965); co-author [with Hans Zeisel \& Bernard Buchholz]), Delax IN the Court (I959). *-

${ }^{1}$ For example, Mrron Brenton; The Privacy Invaders (1964); Vance Packard, The Naked Society (1964). See references collected in Bloustein, Privacy as an Aspect of Human Dignity: An Answer to Dean Prosser, 39 N.Y.U.L. Rev. 962, 963 n.7 (1964).

2I refer to the work of the Association's Special Committee on Science and Law under the chairmanship of Osear M. Ruebhausen, Esq. See, e.g., Ruebhausen \& Brim, Privacy and Behavioral Research, 65 ColuM. L. REv. ir 84 (I965).

${ }^{8}$ Griswold v. Connecticut, 381 U.S. 479 (1965); Poe v. Ullman, 367 U.S. 497 (196r). Thus, in Griswold, Mr. Justice Douglas says: "The foregoing cases suggest that specific guarantees in the Bill of Rights have penumbras, formed by emanations from those guarantees that help give them life and substance." 381 U.S. at 484 . He speaks also of a "zone of privacy created by several fundamental constitutional guarantees." Id. at 485 . And in conclusion he announces, "We deal with a right of privacy older than the Bill of Rights ...."Id. at 486. A similar emphasis on islands of privacy, this time as limiting compulsory disclosures, is found in the Douglas concurring opinion in Gibson v. Florida Legislative Investigation Comm., 372 U.S. 539, 559 (1963). See also Harry Kalven, Jr., The Nrgro AND the First AMiendient II7-18 (1965).

"The several exchanges can be readily traced in H. L. A. Hart, Law, Liberty and Morality (Ig63), and Patrick A. D. Deviln, The Enforcement of Morals (1965).

'Compare George Orwell, I984 (1949). 
It is perhaps still too early in the day to tell whether privacy, however great a value, can function as a constitutional concept. Can, that is, the protection of privacy provide a base from which to reason, a clue for policy? There are at least two difficulties. First, privacy seems a less precise way of approaching more specific values, as, for example, in the case of freedom of speech, association, and religion; ${ }^{6}$ second, there is always the possibility that it cannot be used to delimit the public sphere but will turn out invariably to be residual, simply what is left after the state or society has made its demand.

My immediate concerns, however, are not with these larger issues but with the fate of the law's most direct effort to respond to privacy-the development of a tort remedy for invasions of the right of privacy. And I find myself enmeshed with a paradox. Although privacy is for me a great and important value, tort law's effort to protect the right of privacy seems to me a mistake.

It takes a special form of foolhardiness to raise one's voice against the right of privacy at this particular moment in its history. As we all know, it did not exist as such at common law, ${ }^{7}$ and the first case clearly recognizing it dates from the twentieth century. 8 Its development is a bit of legal culture we are all likely to be proud of: it shows that the "eternal youth" of the common law" is still green; it is a reflection of civilized sensitivity to subtle harms; and, above all, it traces its lineage back to that most influential law review article of all, Warren \& Brandeis, The Right to Privacy.10 Further, all indications are that the tort has come of age, after hesitant beginnings until the 1930s. Our most authoritative commentator advises that there are now some 300 reported cases on privacy in American law reports, and the roll call of states recognizing the right has grown in the interval between the first and third editions of Prosser on Torts from eight to thirty-one with only a handful of states expressly rejecting it. ${ }^{11}$ Moreover, the tort has not only grown; it has, so to speak, multiplied

\footnotetext{
${ }^{\circ}$ See, e.g., NAACP v. Alabama ex rel. Patterson, 357 U.S. 449 (1958), where the Court protects the "privacy" of the membership lists, but does so not because these are private, like the marriage bed in Griswold, but because, under all the circumstances, disclosure of membership in a hostile community will inhibit exercise of the right of free association. Compulsory disclosure, therefore, is a sanction tegulating freedom of association. The point is like the protection of anonymous pamphlets in. Talley $v$. California, 362 U.S. 60 (1960). See generally Harry Kalven, Jr., The Negro and the First AmendMENT 90-r2I (1965). Compare Davis, What Do We Mean by "Right to Privacy"?, 4 S.D.L. Rev. x, x8-20 (1959) (arguing that privacy is "a derivative interest").

'Tee Roberson v. Rochester Folding Box Co., I7I N.Y. 538,64 N.E. 442 (I902).

${ }^{3}$ Pavesich v. New England Life Ins. Co., 122 Ga. x90, 50 S.E. 68 (1905).

The phrase is that of Warren and Brandeis. See text accompanying note 16 infra.

${ }^{10} 4$ Harv. L. REv. 193 (1890). It is to be noted, in view of the popular impression, that the authors speak of the right to privacy rather than the right of privacy and that Warren, not Brandeis, is the first author.

In view of the probable importance of Spahn v. Julian Messner, Inc., 23 App. Div. '2d: 216 ,' 260 N.Y.S.2d 45I, motion to dismiss appeal denied, 16 N.Y.2d 1082, 266 N.Y.S.2d 405, 213 N.E.2d 696 (1965), as a precedent in the privacy field, for one brief, delirious moment I flirted with the idea of calling this essay "Brandeis and Warren Spahn."

${ }^{21}$ Comparc William L. Prosser, Torts 83x-32 (3d ed. 2964) with William L. Prosser; Torts ro52-53 (Ist ed. 194I). The space given in the treatise to discussion of the tort doubles. And it might be remembered that the Restatement in 1934 allocated only one section to it. See Restatement, Torts $\$ 867$ (1934).
} 
and prospered. Dean Prosser a few years ago, after carefully reviewing the cases, argued persuasively that the right of privacy is not one right but is in reality four different ones. ${ }^{12}$ And to make things as awkward as possible for my stance, Dean Wade, following up a Prosser suggestion, then argued that privacy now overlaps defamation to a significant degree, and predicted that we may well see the right of privacy gradually replace the torts of libel and slander, a development of the law he would applaud. ${ }^{13}$ Finally, Professor Bloustein, joining in the remarkable renaissance of serious writing about the tort of privacy in the past five years, has flung the gauntlet at Dean Prosser and has ably attempted to rehabilitate privacy as a single tort, protecting a single fundamental interest. ${ }^{14}$

To reduce my thesis at the outset to capsule form, it is this: I suspect that fascination with the great Brandeis trade mark, excitement over the law at a point of growth, and appreciation of privacy as a key value have combined to dull the normal critical sense of judges and commentators and have caused them not to see the pettiness of the tort they have sponsored. ${ }^{15}$

There is special sense in going in this instance back to the source, not only because the famous article has influenced courts and legislatures but equally because its touch of grandeur and its emphasis on the spiritual side of man seem indelibly to have set the tone for subsequent discussion of the tort. There is a point here for the legal historian to ponder. The impact of the article resides not so much in the power of its argument as in the social status it gave to the tort. In the vernacular of the sports pages, it lent it "class."

The rhetoric is lofty indeed. Thus, at the start: "Political, social, and economic changes entail the recognition of new rights, and the common law, in its eternal youth, grows to meet the demands of society."16 And again: "Later, there came a recognition of man's spiritual nature, of his feelings and his intellect."17 Or again:

This development of the law was inevitable. The intense intellectual and emotional life and the heightening of sensations which came with the advance of civilization, made it clear to men that only a part of the pain, pleasure, and profit of life lay in physical things. Thoughts, emotions, and sensations demanded legal recognition, and the beautiful capacity for growth which characterizes the common law enabled the judges to afford the requisite protection, without the interposition of the legislature. ${ }^{18}$

${ }^{12}$ Prosser, Privacy, 48 Carif. L. Rev. 383 (1960).

${ }^{10}$ Wade, Defamation and the Right of Privacy, I5 VAND. L. Rev. 1093 (1962).

2 Bloustein, supra note 1 . See also the interesting article by Davis, stupra note 6.

${ }^{15}$ The one exception has been Davis, supra note 6, at 23: "Indeed, one can logically argue that the concept of a right to privacy was never required in the first place, and that its whole history is an illustration of how well-meaning but impatient academicians can upset the normal development of the law by pushing it too hard."

${ }^{10} 4$ Harv. L. Rev. at 193.

17 lbid.

${ }^{18} \mathrm{Id}$. at 195. 
And later on, in dismissing the analogy to libel and slander, the authors tell us: "In short, the wrongs and correlative rights recognized by the law of slander and libel are in their nature material rather than spiritual." 19

Yet while the view is long and the right is placed on high ground, there is a curious nineteenth century quaintness about the grievance, an air of injured gentility. "The press is overstepping in every direction the obvious bounds of propriety and of decency. Gossip is no longer the resource of the idle and of the vicious, but has become a trade, which is pursued with industry as well as effrontery."20 And again:

When personal gossip attains the dignity of print, and crowds the space available for matters of real interest to the community, what wonder that the ignorant and thoughtless mistake its relative importance. Easy of comprehension, appealing to that weak side of human nature which is never wholly cast down by the misfortunes and frailties of our neighbors, no one can be surprised that it usurps the place of interest in brains capable of other things. Triviality destroys at once robustness of thought and delicacy of feeling. No enthusiasm can flourish, no generous impulse can survive under its blighting influence. ${ }^{21}$

One may perhaps wonder if the tort is not an anachronism, a nineteenth century response to the mass press which is hardly in keeping with the more robust tastes or mores of today. ${ }^{22}$

More surprising is the fact that the article reads so much like a brief and rests on an incomplete argument. The key analogy is to common law copyright, and the case is rested almost in full on Prince Albert $v$. Strange. ${ }^{23}$ There is a neat point contrasting statutory copyright, which depends on publication and is thus designed to protect property, with the common law rights which exist prior to publication and "are, it is believed, but instances and applications of a general right to privacy, which properly understood affords a remedy for the evils under consideration."24

There can be no objection to the tactic of locating a broader principle behind the protection of intellectual, artistic, and literary property at common law. The difficulty goes rather to the selectivity with which this is done. Even in I890 it must have been abundantly clear that the common law had a highly cautious and ambivalent set of reactions toward giving protection against dignitary and emotional harms, that

\footnotetext{
'20 Id. at 197 .

${ }^{20} I d$. at 196.

s1 Ibid.

${ }^{22}$ It is now well known that the impetus for the article came from Warren's irritation over the way the press covered the wedding of his daughter in $x 890$. Warren and Brandeis had been classmates together at Harvard Law School and had practiced law together. Prosser, Privacy, 48 Calif. L. Rev. 38384, 423 (1960). But see Alpheus T. Mason, Brandeis, A Free Man's Life 7o (1946.) There is, from my special point of view, poetic justice in the circumstance that so petty a tort should have been spawned by so petty a grievance.

${ }^{23} 2$ De G. \& Sm. 652, 64 Eng. Rep. 293 (V.C. 1848 ).

${ }^{24}{ }_{4}$ HARv. L. REv. at 198 . They see common law copyright as protecting against any disclosure, and statutory copyright as protecting the property right in publication. The appropriation subcategory of the right of privacy (see part II infra) is thus the close analogue to statutory copyright; the disclosure subcategory of privacy is the close analogue of common law copyright. It is ironic, given Warren and Brandeis's emphasis, that it is the appropriation version of privacy that has especially flourished.
} 
the law was atomized into pockets of doctrine that pointed in different directions. ${ }^{25}$ Alcorn v. Mitchell, ${ }^{26}$ for an easy example, was on the books in Illinois when Warren and Brandeis wrote. It was a supreme instance of an offensive battery, ${ }^{27}$ the defendant having spat upon the plaintiff in the courtroom. Judgment for a thousand dollars was affirmed. It is transparent that it was the offensiveness, the indignity, and not the physical battery that infuriated the plaintiff, the jury, and the judge. Yet one might have argued, using the Warren and Brandeis logic, that the principle underlying the case supports recognition of insults and indignities as torts, regardless of whether they are accompanied by a technical battery. But surely such an argument would have been simplistic. It is hard to see that the Warren and Brandeis argument for the inevitable growth of an underlying principle is much better. ${ }^{28}$

There are three final points to note about the article. First-and this is particularly relevant in terms of the current Prosser analysis of the multiple aspects of the right of privacy today-Warren and Brandeis were concerned only with public disclosure in the press of truthful but private details about the individual which caused emotional upset to him. Second, there is the question of whether the argument does not prove that if any adjustment in law is to be made, a much broader right ought to be recognized than the one Warren and Brandeis sponsored. If infliction of emotional harm in this special way is now actionable on the grounds of underlying principle, ${ }^{29}$ why should not all intentional infliction of emotional harm be recognized? There has long been criticism of the entire dignitary area of tort law for its lack of coherence, consistency, and adherence to general principle. Yet the Warren and Brandeis effort serves really to add another little ad hoc category.

Finally, while the article is admirable in the care with which it specifies certain limitations on the new right, it makes it apparent at the birth of the right that there are çertain major ambiguities. These are all points which haunt the tort today and

\footnotetext{
${ }^{25}$ See, e.g., cases collected in Charles O. Gregory \& Harry Kalven, Jr., Cases on Torts 787-860 (1959); Magruder, Mental and Emotional Disturbance in the Law of Torts, 49 HaRv. L. REv. ro33 (1936).

${ }_{20} 63$ Ill. 553 ( 1872$)$.

37 "An exasperated suitor has indulged the gratification of his malignant feelings in this despicable mode." Id. at 554 .

${ }^{28}$ Of course, the argument for a single coherent tort of indignity continues to be made from underlying principle. See Prosser, Insult and Outrage, 44 Carrff. L. Rev. 40 (1950); Wade, stupra note 13, at II24-25. And in that oft-quoted observation on "parasitic" damages, Street saw "a transitory stage of legal evolution." I Thomas A. Street, Foundations of Legar Liability 466, 470 (1906).

${ }^{29}$ Wade says that "the principle behind the law of privacy is much broader than the idea of privacy itself." Wade, supra note I3, at II24. He goes on to predict that it will be absorbed as "a part of the larger tort of intentional infliction of mental suffering." Id. at r125. Bloustein, however, argues that it is wrong to read Warren and Brandeis as setting up a remedy for infliction of mental suffering: they were rather protecting something more grand, privacy or "inviolate personality." Bloustein, supra note $x$, at 971 (quoting Warren \& Brandeis, 4 Harv. L. REv. at 205).

There is not, I think, any inconsistency in objecting here that Warren and Brandeis did not carry the underlying principle far enough and objecting above (see text accompanying note 25 supra) that they moved too quickly to the underlying principle. In the latter case the objection is that they failed to confront the ambivalence of the common law on this problem; in the former case the objection is that their argument proved more than they took responsibility for.
} 
to which we will return, but we would note here that there is no effort to specify what will constitute a prima facie case; no concern with how damages are to be measured; no concern, other than to dismiss actual malice, with what the basis of liability will be; and finally there is the projection of a generous set of privileges but no effort to assess whether they do not engulf the cause of action. And, of course, there is no hint that any but gentlemen will ever be moved to use the new remedy.

II

Dean Wade has said that the publication of Dean Prosser's article, Privacy, in $1960^{30}$ is an event rivalling in importance for the law in this area the publication of the original Warren and Brandeis work. ${ }^{31}$ There is, therefore, a certain logic in now moving our discussion from the source to, as it were, the second source.

The earliest cases, Roberson v. Rochester Folding Box Co. ${ }^{32}$ and Pavesich v. New England Life Ins. Co., ${ }^{33}$ and the enactment in 1903 of the New York statute ${ }^{34}$ have long made it apparent that the right of privacy was mixing at least two ideas. ${ }^{35}$ One was that kind of invasion by the press of private life that Warren and Brandeis had as their grievance; the other was akin to appropriation, the use commercially of another's name or likeness without his consent. The rationale for the latter protection, although the matter may be more complex than first appears, ${ }^{36}$ is the straightforward one of preventing unjust enrichment by the theft of good will. No social purpose is served by having the defendant get for free some aspect of the plaintiff that would have market value and for which he would normally pay. In the last decade this point has become fully apparent, and we have had talk of the right to publicity. ${ }^{37}$

What Dean Prosser did was to isolate two additional themes in the privacy cases. One involves intrusions where there is no trespass, as for example the Peeping Tom

\footnotetext{
${ }^{10}$ Prosser, Privacy, 48 Cutif. L. Rev. 383 (1960).

${ }^{21}$ Wade, Developing Trends in the Tort Action for Invasion of the Right of Privacy, I6 VA. L. WeEkLY Dicta COMP. 7 (1965).

s2 I7I N.Y. 538, 64 N.E. 442 (1902).

12122 Ga. 190,50 S.E. 68 (I905).

a N.Y. Sess. Laws 1903, ch. 132, \$§ I-2 (now N.Y. CiviL Righrs Law $\$$ 50-5I).

"Thus, Gregory \& Kalven, op. cit. supre note 25 , treats it twice, once as a dignitary tort, $i d$. at 883-99, and once as a commercial tort, $i d$. at 1255-66. Prosser himself was stressing this aspect back in 1941. "The greater number of privacy cases, however, have involved the appropriation of some clement of the plaintiff's personality for a commercial use." WrLliam L. Prosser, TorTs ro56 (rst ed. 194I). See also Note, Recent Developments in the Right of Privacy, I5 U. CHI. L. REv. 926, 928-29 (ז948).

18 The point is 'best put by Bloustein, supra note $r$, at $985-9 x$. He argues that relatively few of these cases have involved the use of names or likenesses that had a true commercial value; this seems to have been true in Roberson and Pavesich and in such recent cases as Eick v. Perk Dog Food, 347 III. App. 293, 106 N.E.2d 742 (1952), which established the right in Illinois. He argues further that the grievance goes to being "used" by another. I think he is correct that it is possible to have an "appropriation" case that involves not a commercial tort but exactly the same affront to peace of mind that is involved in the disclosure cases. But I am saying simply that the commercial grievance makes sense as a distinct rationale for a tort.

${ }^{87}$ See Harlan Labs., Inc. v. Topps Chewing Gum, Inc., 202 F.2d 866 (2d Cir. 1953), cert. denied, 346 U.S. 8 r6 (1953); Nimmer, The Right of Publicity, rg Law \& Contenr. Prob. 203 (1954).
} 
case or the wire tap on a telephone. It is an interesting challenge to fit in these cases conceptually, but the problem appears de minimis. There is not even a handful of such cases where there is no trespass. ${ }^{38}$ It seems dubious doctrine, therefore, to dignify this cluster as a major subcategory.

The fourth and final Prosser category encompasses what he terms the "false light" cases. A prime example is Hinish v. Meier \& Frank $\mathrm{Co}_{3}{ }^{30}$ where the plaintiff's name without his consent was signed to a telegram to the governor urging defeat of certain legislation. The use of plaintiff's name or picture in advertising without his consent may also often present this form of grievance as well as appropriation. The analogy here is, of course, to defamation, and the overlap might have been thought substantial enough to make an approach via privacy superfluous. It appears, however, that courts are finding it more congenial to assimilate defamation cases to privacy. It in this group of cases that Dean Wade sees as carrying the promise that some day' privacy will replace defamation, ${ }^{40}$ a thesis we will examine later.

It is an important part of Dean Prosser's argument that these aspects of privacy are not only analytically different-as one might say the action of trespass to land protects a variety of interests-but that they are functionally different so that the measure of damages and the appropriate limitations and defenses differ.

It is not easy to know just what to make of this new schema, except that given the legal mind's weakness for neat labels and categories and given the deserved Prosser prestige, it is a safe prediction that the fourfold view will come to dominate whatever thinking is done about the right of privacy in the future. ${ }^{41}$ It is difficult to say whether this reformulation represents a radical revision in analysis, new insight based on the many cases since I94I, or simply new rhetoric. In any event, Warren and Brandeis did not have any such network of privacy protection in mind, and the new analysis dramatically relocates the place of their specific tort of the invasion of private life by the press. On a very small scale, it effects a Copernican revolution.

There may be two consequences from this in addition to useful clarification of messy law, and they may move in opposite directions. On the one hand there is the

\footnotetext{
${ }^{88}$ Prosser is explicit about the overlap with trespass, battery, false imprisonment, and nuisance in the cases he offers; and often the recovery turns on a special statute. See Prosser, Privacy, 48 Caltf. L. Rev. $3^{8} 3,3^{89-92}$ ( 1960$)$.

${ }^{39}$ I66 Ore. $482, \mathrm{II}_{3}$ P.2d 438 (I94I).

${ }^{10}$ Wade, Defamation and the Right of Privacy, 15 VAND. L. REv. 1093, I120-25 (1962).

61 Recent cases utilizing the Prosser scheme are noted $i d$. at rogs n.r3. What is somewhat surprising is the air of discovery with which the new categories have been announced and received. Writing back in I94I, Prosser was explicit that the "right of privacy is rather a group of related rights." William L. Prosser, Torts ro54 (Ist ed. I94I), citing Green, The Right of Privacy, 27 ILl. L. Rev. 237 (1932). Further, he explicitly discussed three groups of privacy cases: intrusion, disclosure, and appropriation. Only the "false light" category seems not to have impressed him as of that date. Finally, Davis, writing in 1959, was emphatic about the mixture of interests combined under the privacy rubric: "If truly fundamental interests are accorded the protection they deserve, no need to champion a right to privacy arises. Invasion of privacy is, in reality, a complex of more fundamental wrongs. Similarly, the individual's interest in privacy itself, however real, is derivative and a state better vouchsafed by protecting more immediate rights." Davis, supre note 6, at 20.
} 
lament eloquently voiced by Professor Bloustein that the whole spirit, dignity, and deep rationale for the tort has now been lost. In place of the grand underlying principle of inviolate personality and individual dignity, we have now four ad hoc categories. Or, to put this another way, the deadening common sense of the Prosser approach cuts the tort loose from the philosophic moorings Warren and Brandeis gave it, from, that is, the excitement of association with the grand norm of privacy. Bloustein's gallant article is in effect an attempt to return analysis of the tort to the moral tone of Warren and Brandeis.

The other consequence of the Prosser schema is paradoxically to inflate the importance of the Warren and Brandeis subcategory of privacy, to lend it a kind of vitality by association. Courts confronted with privacy cases in the future are likely to "hear" only the message that privacy is thriving as a legal concept, with its over 300 cases and thirty-one jurisdictions, that it is complicated and technical, and that it still bears the Warren and Brandeis name.

\section{III}

We come at last to our point, the critique of the Warren and Brandeis category of privacy. We do not aspire here to take on the other three categories. The appropriation tort, as indicated, makes sense; the intrusion tort hardly exists; and the case for the "false light" category, given the law of defamation, will be examined briefly in the next section. Our concern then is with the mass communication tort of privacy.

To begin with, the tort has no legal profile. We do not know what constitutes a prima facie case, we do not know on what basis damages are to be measured, we do not know whether the basis of liability is limited to intentional invasions or includes also negligent invasions and even strict liability.

The conduct, I take it, will involve some reference to the plantiff in the mass media without his consent, which reference must involve the use of his name, his likeness, or some recognizable personal detail of his personality or biography. And, since we are putting the "false light" cases to one side, the reference will be an accurate one. The problem of definition then is to state what less than every such unconsented-to reference is prima facie tortious. This is the problem unless we are to emulate some primitive tribe that believes that any use of one's name somehow magically reduces one's potency. We cannot here follow the strategy the law has been able to use on battery. There can be no analogue to the formula that every unconsented-to touching is prima facie a tort.

What then is the threshold for actionable disclosure in the press of details of privacy? At one time we were told that the invasion must be "conduct which outrages the common decencies ...." Th2 This formula, it should be noted, would have limited the tort to a few exceptional cases and presumably to cases where punitive

\footnotetext{
${ }^{4}$ Wizliak L. Prosser, Torts 1062 (Ist ed. I94I).
} 
damages would be appropriate. This might have provided a viable stopping point; the only difficulty is that few if any of the privacy precedents would satisfy it. Today it is said the formula is that the disclosure must be "one which would be offensive and objectionable to a reasonable man ...." Whatever the success of the reasonable-man standard in negligence cases, in this context it can only mean that the jury will know better than the court what the sensitivities of the day are. The upshot is that every unconsented-to reference in the press creates prima facie a cause of action ${ }^{44}$ that could take the plaintiff to the jury. ${ }^{45}$

The theory of damages is equally vague and mysterious in so far as damages are supposed to be compensatory. It is said that special damages need not be shown and that the difficulty of measuring damages here is no more reason for denying recovery than it would be in defamation. ${ }^{48}$ But it remains odd to give recovery for emotional disturbance without any showing that plaintiff suffered or was upset. And defamation at least has the rationalization that it is trying to infer what degree of injury there has been to reputation and what degree of emotional upset a false and defamatory statement has caused. Surely it is even more conjectural to price the emotional impact of a truthful nondefamatory statement. ${ }^{47}$

Nor has there been much interest displayed in what the underlying basis of liability is, although this has been the standard topic of analysis for all other tort categories. ${ }^{48}$ Does it matter whether the defendant knew the disclosure would be so offensive, or whether he meant to refer to plaintiff at all, or whether he thought he was privileged by the public interest in the item ? $^{49}$ We are concerned, it must be emphasized, with a mass media tort where malicious intention is not likely to appear. In Cason v. Baskin, ${ }^{50}$ would the distinguished author-defendant have had reason to anticipate the outrage with which the plaintiff greeted her portrayal in a novel? In Mau v. Rio Grande Oil, Inc., ${ }^{51}$ was the defendant on notice that the re-enactment of the crime story in which plaintiff had been a victim would so intensively upset the

\footnotetext{
4 Willan I. Prosser, Torts 837 (3d ed. I964). Restatement, Torts $\$ 867$ (I934) spoke of "unreasonable and serious" interference with privacy.

"Dean Wade has argued that the prima facie case approach should be abandoned in privacy actions and something akin to the "negligence" calculus used. Wade, Defamation and the Right of Privacy, Is VAND. L. Rev. I093, Iriz-r6 (r962).

${ }^{13}$ This is perhaps the place to note a curious reversal in the legal fashions of the day. In the personal injury area, it has become fashionable to argue for junking the "reasonable man" standard of behavior, to doubt the capacity and competence of the jury, and to seck to limit damages for pain and suffering. Sec Walter Blum \& Harry Kalven, Jr., Public Lat Perspectives on a Private Law Problem-Auto Conpensation Plans 8-15, 35-36, 76-78 (1965). Yet the reasonable man, the jury, and the award for pain and suffering are all flourishing in commentary on the right of privacy.

"0 Prosser, Privacy, 48 Calrf. L. Rev. 383, 409 (1960). Compare Wade, Defamation and the Right of Privacy, I5 VANd. L. Rev. 1093, III2 (1962).

${ }^{17}$ Warren and Brandeis devote only a casual sentence or two to the damages issue. 4 HaRv. L. REv. 193, 2rg. Given their reliance on the analogy to common law copyright, one might have thought they would favor injunctive relief, but they suggest it "in perhaps a very limited class of cases." Ibid.

${ }^{8}$ See William L. Prosser, Torts 27 (3d ed. I964).

40. Compare Wade, Defamation and the Right of Privacy, 15 VANd. L. REv. 1093, I110-I1 (1962).

${ }^{50}$ I55 Fla. 198, 20 So. 2d 243 (1945).

${ }^{82} 28$ F. Supp. 845 (N.D. Cal. 1939).
} 
plaintiff? In Kerby v. Hal Roach Studios, Inc., ${ }^{52}$ where the defendant employed an advertising gimmick of letters from "your ectoplasmic playmate, Marion Kerby" and was unaware there was an actual Marion Kerby living in Los Angeles, was liability imposed for a negligent failure to check the telephone directory, or did the defendant risk invasion of privacy at its peril? It is once again characteristic of the indifference to the legal profile of the tort that there is virtually no discussion in the books of whether or not privacy is an intentional tort. And this is especially striking since the underlying basis of liability for defamation has been so famous a point of tort doctrine. $^{53}$

This is perhaps the place to pause to reflect on the rule that truth is a defense in defamation. Although the rule has considerable venerability, there has been some controversy over its policy in recent years. There have been articles urging that truth as a defense be qualified, ${ }^{54}$ and about ten jurisdictions have by statute made moves in this direction..$^{55}$ What is arresting here is that none of the critics argue for more than a change that would make truth a defense only if uttered with good motives. If we come at the matter from the angle of defamation, liability for disclosing a truth about the plaintiff would at most be actionable only if the defendant published with bad motives. If this is as far as we have been willing to go in defamation, where the disclosure is negative enough to injure reputation, why do we expand the liability rule when we come at the grievance as an invasion of privacy?. If privacy were to have been made consistent with the old tort of defamation, it would have been a stringent form of intentional tort requiring something akin to ill will. Perhaps as Dean Wade suggests it is the old that should conform to the new; defamation should now be made consistent with privacy. But in any event the strained relationship of truth in privacy to truth in defamation is one more indication that the law has been oddly indifferent to working out any serious definition of the newer tort. ${ }^{56}$

The fact that we have no intelligible version of a prima facie case is only half the difficulty; the other half is that since Warren and Brandeis wrote, it has been agreed that there is a generous privilege to serve the public interest in news. And

\footnotetext{
${ }^{59} 53$ Cal. App. 2d 207, r27 P.2d 577 (Dist. Ct. App. 1942).

so See Gregory \& KalveN, op. cit. supra note 25, at 982-96; William L. Prosser, Torts $790-95$ (3d ed. 1964); Smith, Jones v. Hulton: Three Conficting Jidicial Views as to a Question of Defamation, 60 U. PA. L. REv. 365 (r912).

" Franklin, The Origins and Constitutionality of Limitations on Truth as a Defense in Tort Law, I6 Stan. L. Rev. 789 (1964); Harnett \& Thornton, The Truth Hurts: A Critique of a Deferse to Defamation, 35 VA. L. Rev. 425 (I949); Ray, Truth: A Defense to Libel, I6 Minn. L. Rev. 43 (I93I).

${ }^{56}$ See Willial L. Prosser, Torts 824 (3d ed. I964).

${ }^{\text {vo }}$ It may lend perspective to the right of privacy too if we approach it for a moment as an instance of the emerging generic tort of intentional infliction of emotional harm, as Wade, Defamation and the Right of Privacy, I5 VAND. L. REv. 1093, II24-25 (1962), has urged. For example, the formula proposed by Prosser, Instll and Outrage, 44 Calif. L. Rev. 40, 43 (1956), was this: "One who, by extreme and outrageous conduct, intentionally or recklessly causes severe emotional distress to another is subject to liability for such emotional distress and for bodily harm resulting from it" (all italicized in original) (quoting Restatement (SEcond), Tonts $\S_{4} 6(\mathrm{I})$ (Tent. Draft No. I, I957)). Has there been a single privacy case that satisfies this standard?
} 
today, since New York Times Co. v. Sullivan, ${ }^{57}$ the privilege may arguably have some constitutional status. What is at issue, it seems to me, is whether the claim of privilege is not so overpowering as virtually to swallow the tort. What can be left of the vaunted new right after the claims of privilege have been confronted?

To begin with the Warren and Brandeis dictum, privacy inherits all the privileges of libel and slander together with an additional privilege to publish, in their words, "matter which is of public or general interest." defamation, there is a privilege to report news. I need not for my purposes push the point to its logical extreme, but surely there is force to the simple contention that whatever is in the news media is by definition newsworthy, that the press must in the nature of things be the final arbiter of newsworthiness. The cases admittedly do not go quite this far, but they go far enough to decimate the tort.

In Jenkins v. Dell Publishing Co., ${ }^{69}$ Judge Hastie found a sufficient public interest to exonerate defendants for republishing in a magazine called Front Page Detective, a year after the event, the story of how Jenkins had been kicked to death by a teen-age gang. The story was told in a one-page account with 150 words and several photographs. Judge Hastie declined to distinguish furnishing news for entertainment and for information.

In Metter v. Los Angeles Examiner, ${ }^{80}$ the plaintiff's wife committed suicide by jumping from a high building, and the news accounts featured photographs of the event despite the request of the anguished husband. The court, in finding the newspaper coverage privileged, argued that, by the method she chose, Mrs. Metter had made herself a public figure forfeiting all right to privacy. "For a brief period and in the pitiful and tragic circumstances attending her demise she became an object of public interest." ${ }^{\$ 101}$

And again in Kelley v. Post Publishing $\mathrm{Co}^{62}$ the defendants published a photo of the body of plaintiff's daughter immediately after her death in an auto accident. The court stoically confronting the needs of the public interest observed: "But if the right asserted here were sustained, it would be difficult to fix its boundaries . . . .

\footnotetext{
${ }^{67} 376$ U.S. $254(1964)$. See generally Kalven, The New York Times Case: $A$ Note on the Central Meaning of the First Amendment, 1964 Sup. CT. Rev. 191. There is a possibility that the newsworthiness privilege in privacy will acquire constitutional status and thus become independent of state policy. This would alter some of Dean Wade's expectations of flexibly incorporating any free spech privilege in privacy cases into a negligence-like calculus. See note 44 supra.

The constitutional issue is now on appeal before the U.S. Supreme Court in Hayes v. Hill, 15 N.Y.2d 986, 207 N.E.2d 604, prob. juris. noted sub nom. Time, Inc. v. Hill, 382 U.S. 936 (1965), reargument ordered, $3_{4} 8$ U.S. 995 ( 1966 ). See generally Franklin, A Constitutional Problem in Privacy Protection: Legal lnhibition on Reporting of Fact, I6 Stan. L. Rev. 107 (1963). See also, Franklin, The Origins and Constitutionality of Limitations on Truth as a Defense in Tort Law, 16 STAN. L. Rev. 789 (1964).

${ }^{\text {so }} 4$ HaRv. L. REv. at $2 \mathrm{r} 4$.

50 25 I F.2d 447 (3d Cir. I958).

${ }^{60} 35$ Cal. App. 2d 304, 95 P.2d 491 (Dist. Ct. App. 1939).

${ }^{61}$ Id. at 312, 95 P.2d at 496.

${ }^{62} 327$ Mass. 275, 98 N.E.2d 286 (I951).
} 
A newspaper could not safely publish the picture of a train wreck or of an airplane crash if any of the bodies of the victims were recognizable." ${ }^{263}$

The lack of legal profile and the enormity of the counterprivilege converge to raise for me the question of whether privacy is really a viable tort remedy. The mountain, I suggest, has brought forth a pretty small mouse. Let me sum up my complaint by citing three cases which in my view frame the weaknesses of the tort: Cohen $v$. Marx, ${ }^{64}$ Cason v. Baskin, ${ }^{65}$ and of course Sidis v. F-R Publishing Corp. ${ }^{66}$ In the Cohen case the plaintiff, a former boxer, sued the comedian, Groucho Marx, for having said on a radio show: "I once managed a fighter named Canvasback Cohen. I brought him out here, he got knocked out, and I made him walk back to Cleveland." It is true that the court in this instance declined to protect Mr. Cohen's privacy. I offer the case simply as an example of the unbeatable triviality of some privacy litigation.

Cason involved the effort of Marjorie Kinnan Rawlings to use plaintiff as a character in her book, Cross Creek. The following is a fair example of the characterization of which plaintiff complained:

Zelma is an ageless spinster resembling an angry and efficient canary. She manages her orange grove and as much of the village and county as needs management or will submit to it. I cannot decide whether she should have been a man or a mother. She combines the more violent characteristics of both and those who ask for or accept her manifold ministrations think nothing of being cursed loudly at the very instant of being tenderly fed, clothed, nursed or guided through their troubles. ${ }^{67}$

The case went up to the Florida Supreme Court twice. On the first occasion the court reversed, holding plaintiff stated a prima facie case, and thereby entered Florida among the states recognizing a right of privacy. The case came back on appeal after a trial resulting in a verdict for the defendant. The court again reversed, this time because evidence about defendant's status as an author had erroneously been admitted; it went on, however, to note that plaintiff had failed to offer any evidence on the matter of compensatory damages and to remand with directions that the judgment for the defendant be reversed and that plaintiff recover only nominal damages. 'Twas, as the poet said, a famous victory.

Sidis involved the New Yorker profile of a one-time child prodigy who in adulthood, after a brilliant youth, had dwindled to a career as an "insignificant" clerk desirous of anonymity and given to odd enthusiasms such as elaborately collecting streetcar transfers. The facts in Sidis present a very appealing case, if there is to be a legal right of privacy. Here we have a detailed disclosure of personal life at the expense of one who manifestly wished "to be let alone." Yet even here, as the logic of Judge Clark makes inexorable, there is no liability. Sidis, argues Judge Clark,

\footnotetext{
id Id. at $277-78,98$ N.E.2d at 287 .

${ }^{\circ} 94$ Cal. App. 2d 704, 211 P.2d 320 (Dist. Ct. App. 1949).

ot 55 Fla. 198, 20 So. 2d 243 (1945).

${ }^{60}{ }_{113}$ F.2d 806 (2d Cir. 1940).

a7 I55 Fla. 198, 202-03, 20 So. 2d 243, 245 (I945), quoting Marjorie Kinnan Rafrings, Cross Creek
} $4^{8}$ (1942). 
was inescapably public. Originally at the height of his brilliance he was a public figure. "Since then Sidis has cloaked himself in obscurity, but his subsequent history, containing as it did the answer to the question of whether or not he had fulfilled his early promise, was still a matter of public concern."

The final point to make against the tort rests to a considerable extent on a surmise. It goes to claims consciousness. It goes to who will be recruited as plaintiffs under this tort, and we need some empirical data about the handling of privacy claims. We know a little something about claims consciousness in the personal injury field, ${ }^{09}$ and we know there is a pronounced and interesting difference between English culture and our own in terms of readiness to sue for libel. ${ }^{70}$ We can at this point only guess about privacy.

I have two guesses. The first is that the victims on whose behalf the privacy tort remedy was designed will not in the real world elect to use it and that those who will come forward with privacy claims will very often have shabby, unseemly grievances and an interest in exploitation. I would think, for example, that a parent ruthlessly photographed at the terrible moment of picking up the body of his child seriously hurt or perhaps killed in an accident would have an appealing case against the intrusion into his moment of grief; this is "news" we might well ask the public to forgo. ${ }^{71}$ But I would also think that the parent I have in mind would not deign to sue for money damages. ${ }^{72}$ I am emboldened, therefore, to assert that privacy will recruit claimants inversely to the magnitude of the offense to privacy involved.

It is an old story that law must tolerate some fraud and exploitation of its processes, but the challenge here is narrower. In the law at large there is a rough favorable balance between claims we would wish the law to honor and exploitative claims. Hence, most remedies seem worth their price in shabby assertions of right. But it is possible for the balance to get thrown off, for primarily unattractive claimants to seek to use the remedy. Perhaps the one major experience the law has had with the balance of claims going askew is with redress for breach of promise. The balance finally became so bad that in many jurisdictions the remedy was abolished. As one commentator put it: "The plaintiffs who do recover are not the ones who should,

\footnotetext{
${ }^{68}$ II3 F.2d at 809.

There appears to be some difficulty in locating the precise rationale for Sidis. I read it as a definitive precedent on the newsworthy privilege. . Prosser, however, reads it as "the outstanding case" on the reasonable man test of privacy: ". . . the decision that there was no cause of action rested upon the ground that there was nothing in the article which would be objectionable to any normal person." Prosser, Privacy, 48 CAIIF. L. Rev. 383, 397 (1960).

${ }^{\circ}$ See Roger B. Hunting \& G. S. Neuwirth, Who Sues in New York City? (1962); Hans Zeisel, Harry Kalven, Jr. \& Bernard Buchiolz, Deiay in the Court 223 (1959).

${ }^{70}$ Kalven, Book Review, 22 U. CHr. L. Rev. 582, 583 (1955).

${ }^{71}$ But see Kelley v. Post Publishing Co., 327 Mass. 275, 98 N.E.2d 286 (1951), holding there is a privilege.

${ }^{72}$ Yet the father did sue in Kelley, supra note $7 \mathrm{r}$; the husband did sue in Metter v. Los Angeles Examiner, 35 Cal. App. 2d 304, 95 P.2d 49I (Dist. Ct. App. 1939); and the parents of the deformed baby did sue in Bazemore v. Savannah Hospital, 171 Ga. 257, I55 S.E. 194 (1930).
} 
and the persons who are wronged in this way practically never bring suit." ${ }^{\text {"3 }}$ Of course, breach-of-promise suits had come to involve fraud and blackmail, and there is no parallel stain on privacy actions. What is similar, however, is that in both instances the cause of action on paper looked attractive and meritorious and that the victim that society had in mind when it created the means of redress was not the one who used the remedy. Thus, my question is this: Would we have created the tort remedy for invasion of privacy had we foreseen what the cases brought under it to date have amounted to?

My second guess about the handling of privacy claims is that they take their toll in the settlement process. The lack of legal profile for the tort makes any sort of unconsented-to reference to the plaintiff look colorable, and there is the threat of indeterminate damages. I suspect, therefore, that the achievement of the new tort remedy has been primarily to breed nuisance claims.

I have put my suspicions in the form of guesses. It would have been more appropriate perhaps simply to state them as questions. I am writing from a most inadequate sample of legal anecdotes and bare impressions gained from case reports. The dynamics of claims consciousness is a tricky business, and I could easily be wrong. Dean Wade, after all, has told us that experience in the three Southern states which have insult statutes has been quite satisfactory $;^{74}$ a priori the insult statute would seem as open to claimant abuse as the right of privacy.

The right of privacy is preeminently an instance where the law in action may change the significance of the law in the books. What we need to know for further discussions of this tort is this: Who sues in privacy?

\section{IV}

The mysterious way in which the common law grows and changes has never found better illustration than in the current tendency of privacy actions to move into the traditional field of defamation. Warren and Brandeis, despite their tributes to the "eternal youth of the common law," would have been astonished to learn that the precedent they launched would grow so that today, in Dean Wade's wording, "the great majority of defamation actions can now be brought for the invasion of the right of privacy . ..";5 they would have been further amazed to be told as of the I 960 s that "the action for invasion of the right of privacy may come to supplant

\footnotetext{
73 Brown, Breach of Promise Suits, 77 U. PA. L. Rev. 474, 493 (1929).

${ }^{3}$ Wade, Tort Liability for Abusive and Instuling Language, 4 VAND. L. REv. 63, 90-9I (1950). Compare Dulieu v. White \& Sons, [I90I] z K.B. 669, 68I (Statement of Kennedy, J.): ". .. I should be sorry to adopt a rule which would bar all such claims [for emotional harm negligently inflicted], on grounds of policy alone, and in order to prevent the possible success of unrighteous or groundless actions. Such a course involves the denial of redress in meritorious cases, and it necessarily implies a degree of distrust, which I do not share, in the capacity of legal tribunals to get at the truth in this class of claim"; Wrlinar L. Prosser, Torts 43 ( $3 \mathrm{~d}$ ed. r964), answering the fear that recognition of emotional harm will result in multiplicity of suits and fraudulent and trivial claims.

${ }^{75}$ Wade, Defamation and the Right of Privacy, 15 VAND. L. REv. I093, II2I (1962).
} 
the action for defamation." The Thed scrupulously set their new tort beside the traditional rules for libel and slander and had accepted the argument that a limitation that applied to redress of a statement that was defamatory and false should apply a fortiori to redress of one that was nondefamatory and true. It would have been expected that the relationship of privacy to defamation would be that privacy would now make some true statements actionable and thus qualify the defense of truth in defamation. What the "false light" cases suggest, however, is a role for privacy actions where the statement is false.

I find both conceptual and practical difficulties in this new development. Conceptually I am not sure I see what the invasion of privacy consists of. Is it an invasion of privacy to say falsely of a man that he is a thief? What is his grievance? Is it that, on analogy to Melvin v. Reid, ${ }^{77}$ it would have been an invasion if true and no one had known it? Or is it that it is false? Or is it that his name has been used in a public utterance without his consent? The first idea seems to me preposterously oblique and complex; the second is surely covered by the law of defamation; the third is trivial.

Is the case for the use of privacy better if we assume that the statement, although false, would not be actionable in defamation? The literal and total overlap with defamation is then avoided, but is our judgment of the grievance any more intelligible? If the statement is not offensive enough to the reasonable man to be defamatory, how does it become offensive enough to the reasonable man to be an invasion of privacy? Or is the point again that plaintiff's name has been used without his consent? And if the desire is to relax somewhat the criteria of what is defamatory, would it not be more rational to do that openly and directly?

The result seems to be the emergence of privacy cases that define a hybrid tort, cases where the use of a name without consent is held to be offensive because the attribution is false and where the answer to its being nondefamatory is that it is a use of the name without consent! ? $^{78}$

All this does not do justice to the elegance of Dean Wade's review of the cases or his argument from them. He argues first that the plaintiff surely cannot be worse off because the statement is false, that, therefore, he should be able to sue without regard to whether it is true or false, and finally that, if this step is taken, a majority of all defamation actions can be restated as privacy actions. ${ }^{79}$ I would agree, of course, that the plaintiff should not have to prove the truth of the assertion in order to state a

\footnotetext{
${ }^{70}$ Ibid.

${ }^{77} 112$ Cal. App. 285, 297 Pac. 91 (Dist. Ct. App. 1931).

${ }^{8}$ There are two important cases that are illustrative of this approach: Spahn v. Julian Messner, Inc., 23 App. Div. 2d 216, 260 N.Y.S.2d 45I, motion to dismiss appeal denied, 16 N.Y.2d 1082, 266 N.Y.S.2d 405,213 N.E.2d 696 (1965), and Hill v. Hayes, 15 N.Y.2d 986, 207 N.E.2d 604, prob. juris. noted sub nom. Time, Inc. v. Hill, 382 U.S. 936 (1965), reargument ordered, 384 U.S. 995 (1966). In both cases recovery under the New York privacy statute turned on "fictionalization" or "falsity." 'The final disposition of these cases is certain to have substantial influence nationally on the law as to the tort of privacy.

${ }^{70}$ Wade, Defamation and the Right of Privacy, 15 VAND. L. REv. 1093, I120-21.
} 
cause of action for privacy. He should not, however, be allowed to bolster a claim for privacy on the ground that the statement is false. It seems to me an extraordinary torturing of categories now to view defamation as resting ultimately not on the falsity but on the use of plaintiff's name without his consent.

Dean Wade further argues that use of privacy permits defamation at last to recover from what Pollock called "its going wrong at the outset," the matter as injury to reputation rather than to feelings; that it permits the use of a "negligence calculus" structure rather than the rigid prima facie case-privilege structure of defamation; that it permits escape from the arbitrariness of the libelslander distinction; and that it will permit a more flexible and candid appraisal of the free-speech issues involved in defamation cases. These are all beautiful points about the possibility of the new reforming the old by the slow evolution of common law processes, and Dean Wade may well be right in his prediction.

But if the colonization of defamation by privacy does take place, it will only be because by the use of a fiction the courts have turned at last to the reform of the law of defamation. It will not be because they have perceived that logically defamation is subsumed in privacy. They will simply be calling false statements by a new name.

Finally, one may wonder if this trend represents even good judicial statesmanship. ${ }^{81}$ The technical complexity of the law of defamation, which has shown remarkable stamina in the teeth of centuries of acid criticism, may reflect one useful strategy for a legal system forced against its ultimate better judgment to deal with dignitary harms. Perhaps the famous Pollock dictum had the matter exactly wrong!

In any event, it would be a notable thing if the right of privacy, having, as it were, failed in three-quarters of a century to amount to anything at home, went forth to take over the traditional torts of libel and slander. ${ }^{82}$

\footnotetext{
${ }^{80} 1 d$. at 1122 \& n.r6r.

91 Prosser has expressed some dismay at the ease with which defamation bastions seem to be falling to privacy. "Are they of so little consequence that they may be circumvented in so casual and cavalier" a fashion?" Prosser, Privacy, 48 Calif. L. Rev. 383, 401 (r960).

s9 "All this is a most marvelous tree to grow from the wedding of the daughter of Mr. Samuel D. Warren." Id. at 423 .
} 